\title{
The Risk \& Chance of Japanese Enterprises in Chinese Market
}

\author{
Jin Chen \\ Ritsumeikan University, Ibaraki, Osaka, Japan
}

\begin{abstract}
This paper presents a new viewpoint for Japanese enterprises in Chinese market development by analyzing in particular the risk and chance in the Chinese market, and searching the new cooperation way between enterprises of Japan and China. The production cost is uprising along with the increase of personnel expense, and the competitiveness of export decreases more with high RMB in recent China. In particular, the production of the labor concentration type product like apparel and miscellaneous goods are transferred to as South East Asia and Africa with lower labor cost. But, a crisis always has both sides of risk and chance. Competitive as production base for export is subverting, China as a huge developing market, is still very attractive. China as world factory has become world market. The consumption market of middle class is growing rapidly following upper class. The productivity up and industrial sophistication are urgent tasks for China, deprived of its competition predominance as cheap workforce. Industrialization is achieved in China, on the other hand, people's indignation is enhancing by pollution of air, soil and water. Under the pressure of environment pollution and increasing costs, Chinese companies have strong desire for the introduction of both energy saving technology and equipment and their know-hows of energy-saving and productivity increasing from the Japanese companies. The introduction of Japanese excellent energy-saving technique \& equipment, know-how of productivity increasing to China will be big business opportunity for Japanese company.
\end{abstract}

Keywords: Chinese market, risk, chance, energy saving, productivity increasing

\section{Introduction}

This paper presents a new viewpoint for Japanese enterprises in Chinese market development by analyzing in particular the risk and chance in the Chinese market, and searching the new cooperation way between enterprises of Japan and China.

The Japanese enterprises invested in the Chinese market are confronted with crisis in recent years due to the deterioration of Japan-China relationship. The enterprises advanced in and heading for the Chinese market are encountered with severe damage and shock especially after the anti-Japanese demonstration and conflict in China caused by East China Sea dispute in September, 2012. Afterwards, "cold political relations but hot economic relations" have collapsed. Moreover, a stall of Chinese economic growth and a rise of the personnel expenses also occur at the same time.

But, a crisis always has both sides of risk and chance. The middle class consumption in China is expanding significantly following the wealthy class along with the increase of national income in recent years. Competitiveness of production base for export become weaker, but China as a huge developing market, is still very attractive. Meanwhile, under the pressure of environment pollution and increasing costs, Chinese

Jin Chen, Professor, College of Business Administration, Ritsumeikan University. 
companies have strong desire for the introduction of both energy saving technology and equipment and the know-hows of energy-saving and productivity increasing from the Japanese companies.

First, this paper reconfirms the sequence of the economic growth and market expansion in China so far. Secondly the paper dissects the conversion with the Chinese economic growth pattern and related issue, especially the risk with Japanese enterprise is confronted. Furthermore, the chance for Japanese company in the Chinese market is more explored.

\section{Japan and China in Asia Economic Growth}

\section{Trade Increase and Market Expansion of Asia}

Asian development is achieved by increasing export. The core of development mechanism is "export oriented industrialization". Asian countries have achieved their advanced industrialization and economic growth by the pattern of importing and processing the intermediate \& capital goods from Japan, employing plentiful labor with low wages and exporting to Europe and America (Chen, 2014, pp. 5-7).

Japan depends more and more on the Asian economy with the growth of Asian economy. Based on 2010 trade statistics released by Ministry of Finance Japan (MOFJ) on Jan. 27, 2011, the ratio of Asia among the trade amount with export and import sum total was 51\%, which broke through $50 \%$ for the first time. The trade amount to China accounted for $20.7 \%$ in 2010, which became Japan's biggest trading partner. Even though China is the biggest trading partner to Japan, Japan is still playing active role in trade deregulation to ASEAN as export base as well.

The total trade amount of Japan within Asia in 2010 was 65 trillion and 302.8 billion JP yen, increased $24.8 \%$ of last year. The ratio holding in the trade total amount of Japan rises 1.5 points which is the highest after 1979 with available record. The ratio in Asia has rising about 10 points, on the contrast the ratio in the USA is $12.7 \%$, decreased almost half within these 10 years.
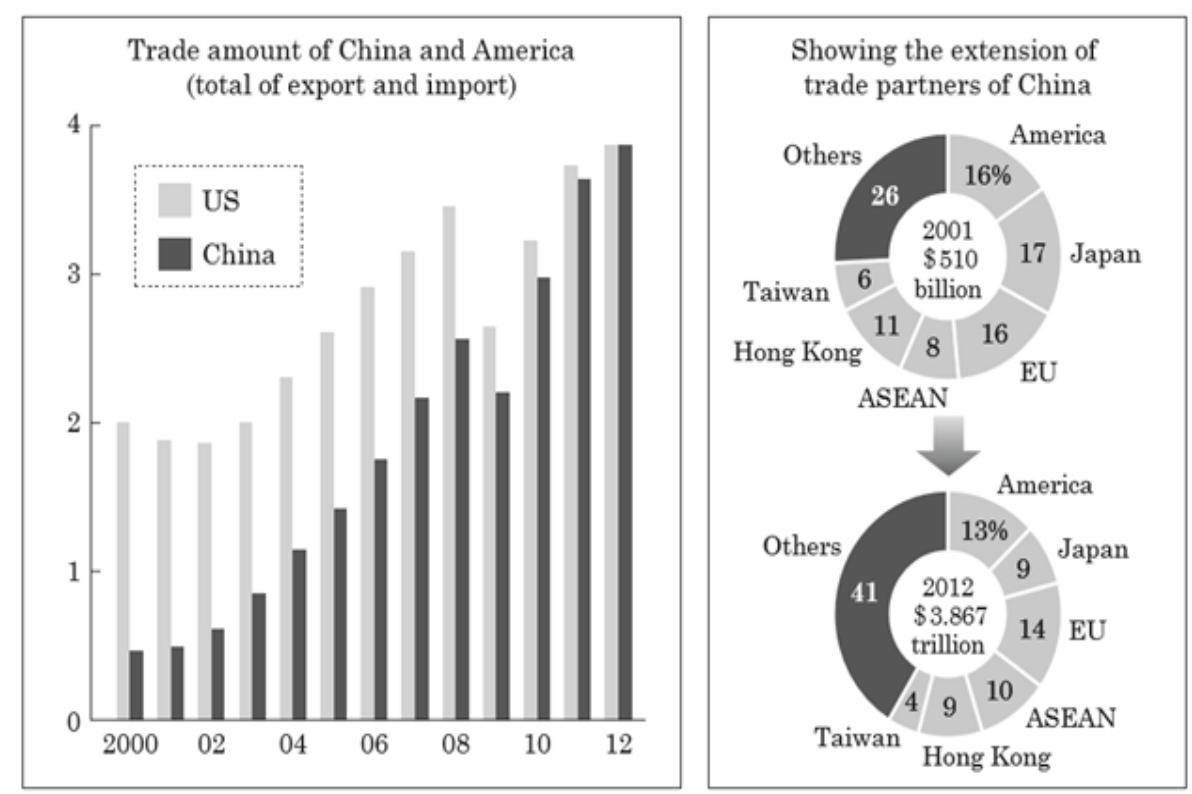

Figure 1. Increasing of China trade amount and trade expansion in Asia in 2012.

Note. Based on the investigation of United States Department of Commerce \& General Adminstration of Customs of China. Souces: Nikkei (Japan economics times), February 10, 2013. 
On the other hand, the Chinese presence in the global economy and world trade is ascending. After 1979 reform and opening-up, China is called "World Growth Center" with great deal of foreign currency investment. The economic growth rate has maintained up to two digits for more than 30 years. The GDP scale in 2010 has ranked second, after America but over Japan. The goods trade total amount with export and import in 2012 stood America without the world top (left axis in Figure 2). On the other hand, the trade between China and ASEAN is increasing rapidly, while Asia is becoming a huge consumer market at the same time (right axis in Figure 1).

\section{Simultaneous Expansion in Upper and Middle Class Market}

The poor class which is a problem in developing country decrease rapidly in China, while there is a phenomenon that the population of so-called middle class ${ }^{1}$ increases significantly, that is, not only an average income is rising but also the middle income class is increasing explosively. According to the estimation of World Bank, 54\% of the population belonged to the poor class (less than US \$1.25 per day) in 1995 in China, while in 2005 , it dropped down to $16 \%$. On the other hand, the ratio of middle class (US \$2 8 per day) increase from $26 \%$ to $57 \%$.

Table 1

Predicated Increasing of Middle \& Rich Class in Emerging Countries

\begin{tabular}{|c|c|c|c|c|c|c|}
\hline & \multicolumn{3}{|c|}{ Upper Middle Class } & \multicolumn{3}{|c|}{ Upper class } \\
\hline & \multicolumn{3}{|c|}{ Annual household income (US\$15,000-\$35,000) } & \multicolumn{3}{|c|}{ Annual household income (US\$35,000--) } \\
\hline Unit: 10,000 people & 2010 & 2020 & Increase & 2010 & 2020 & Increase \\
\hline China & 12,000 & 39,000 & $225.0 \%$ & 4,000 & 7,000 & $75.0 \%$ \\
\hline India & 5,000 & 28,000 & $460.0 \%$ & 18,00 & 67,00 & $272.2 \%$ \\
\hline Indonesia & 1,000 & 5,500 & $450.0 \%$ & 300 & 1,200 & $300.0 \%$ \\
\hline Brazil & 6,000 & 8,000 & $33.3 \%$ & 4,000 & 7,000 & $75.0 \%$ \\
\hline Pakistan & 600 & 2,000 & $233.3 \%$ & 300 & 800 & $166.7 \%$ \\
\hline Russia & 4,000 & 6,000 & $50.0 \%$ & 1,000 & 6,000 & $500.0 \%$ \\
\hline Turkey & 3,500 & 2,900 & $-17.1 \%$ & 1,800 & 4,400 & $144.4 \%$ \\
\hline Nigeria & 300 & 700 & $133.3 \%$ & 100 & 300 & $200.0 \%$ \\
\hline
\end{tabular}

Source: Research report announced by Japan Minstry of Economy, Trade and Industry in March 2012.

China is achieving firm economic growth and its consumption market of middle class is expanding rapidly following the upper class in the 21st century. It is predicted that the upper and middle classes in China will expand with high speed (see Table 1).

The growth engine of Japanese company has also shifted to Asia from Europe and America with the market expansion in Asia. According to Overseas Business Activities Basic Research (see Figure 2) of Japan Ministry of Economy, Trade and Industry, Asia occupies overwhelming ratio in the overseas expansion destination of Japanese company, and the ordinary profit earned from Asia is absolutely more than Europe and America.

\section{Conversion of the Chinese Economic Growth Pattern and Issues}

\section{From the World Factory to the World Market}

Even after the 2008 world financial crisis, China is achieving firm economic growth and its consumption

\footnotetext{
1 The middle class is between upper class and poor class. The middle class is measured by household income and the consumption scale, which has no clear definition as for poor class. World trend is measured by absolute numerical value, but there is also a separating investigation in the respective countries.
} 
market of middle class is expanding rapidly following the upper class. According to the survey on the "2011 Foreign Direct Investment Reliability” summarized by A. T. Kearney which is a major American management consulting firm, China maintains its top ranking from 2002 with the background of the growth of service industry (see Table 2) ${ }^{2}$. Therefore, China as world factory has become world market along with its economic growth. The number of people in China who have cell phones, home appliances, motorcycles, and even cars are further increasing (Chen \& Mori, 2014).

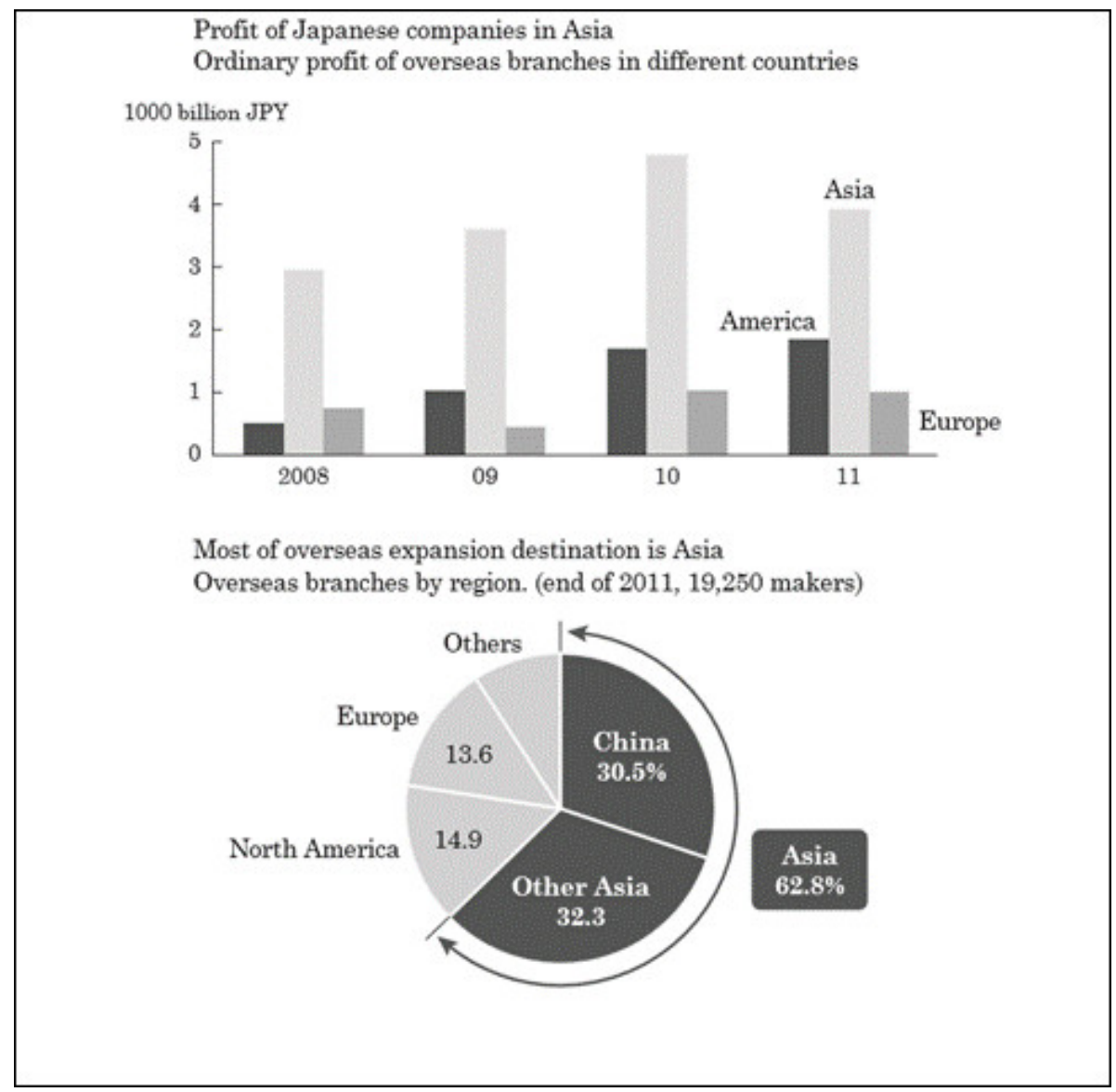

Figure 2. Asia as a main profit source for Japanese company.

Source: Nikkei (Japan Economic Times), May 8, 2013; Overseas Business Activities Basic Reseach (questionnaire survery respondents companies) of METI.

Table 2

2011 Foreign Direct Investment Reliability

\begin{tabular}{|l|l|l|l|}
\hline $1(1)$ & China & $6(7)$ & Australia \\
\hline $2(3)$ & India & $7(24)$ & Singapore \\
\hline $3(4)$ & Brazil & $8(10)$ & UK \\
\hline $4(2)$ & US & $9(20)$ & Indonesia \\
\hline $5(5)$ & Germen & $10(21)$ & Malaysia \\
\hline
\end{tabular}

Resource: Nikkei Asian Review, Dec. 8, 2011.

Note. The number in ( ) refers to the ranking based on the survey in 2010.

2 This survey was implemented to chief managers responsible for direct investment in 17 companies, 27 countries in Oct. 2011, focusing on the merits as investment partner. Emerging countries account for 50\% among 25 top ranking countries, 
In Figure 3, the Pyramid of the Chinese Market shows the general correspondence among BOP (Base of the Pyramid = lower class), MOP (Middle of the Pyramid = middle class), TOP (Top of the Pyramid = upper class). MOP market refers to the second tier wealth group with GDP per personal income over \$3,000 per year (Defined by Japan Ministry of Economy, Trade and Industry). The newly rich group is increasing in size over the second tier wealth group, which is currently the target of market penetration for Japanese companies. In China, there are 220 240 million of the second tier wealth and 260 280 million of newly rich class in 2008 . The middle class (MOP) market in all of Asia contains about 900 million people which accounts for $65 \%$ of the middle class in the world.

The GDP per person double increased to $\$ 7,500$ in 2014 compared with $\$ 3,400$ in 2008. Therefore the former income line between MOP and DOP has increased from $\$ 3,000$ (line going down) to $\$ 6,000$. MOP population over $\$ 3,000$ line is estimated to increase to one billion at present from 500 million in 2008.

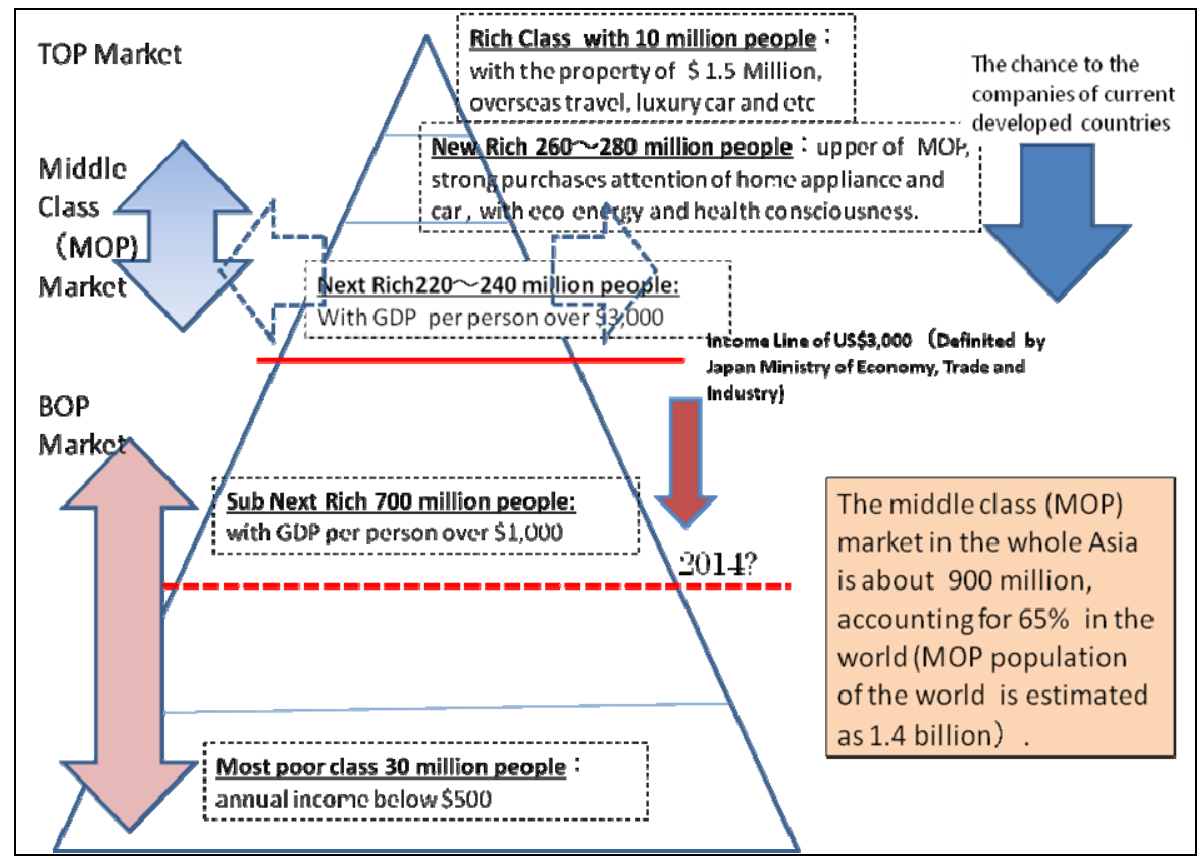

Figure 3. Pyramid of Chinese Market and three Classes in 2008.

Source: Amano, 2009.

Urbanization for consumption improvement is promoting rapidly in China at the same time. The government will invest 40 trillion RMB yuan for 10 years from 2011 to 2020 according to the Chinese urbanization plan, with the construction of 20 urban groups, 180 cities and 10,000 towns. Upon the urbanization in such area, it is possible to achieve the conversion to the consumption oriented economic system along with increasing economic productivity, as the result of investment piling and 2nd \& 3rd industrial percentage $^{3}$.

\section{Stall of Economic Growth and Rise of Personnel Expenses}

Chinese economic growth stalls in recent years. The economic growth rate of China has maintained its high level for three decades till 2011. The annual average growth ratio is around 10\%, and the ratio in 2012 was

\footnotetext{
${ }^{3}$ Based on the first draft of National Development Plan for the Promotion of Urbanization (2011-2020), led by National Development and Reform Commission.
} 
7.8\% and 7.7\% in 2013. The substantial domestic GDP in 2014 has increased 7.4\%, in 2015 has increased 6.9\%. Therefore it is obvious that Chinese economy is stalling.

The salary raise and labor shortage occur at the same time in China now. The minimum wages in China retains raising more than $10 \%$ every year for decades and the average wage rises in double by approximately five years which depresses the profit of the local Japanese company. Moreover, the guarantee of workers is tough owing to the decreasing of working away from home workers and high request for employment. For example, $6 \%$ of total working away from home workers equal to one million workers in Guangdong Province was insufficient around 2014 Chinese Lunar New Year.

It's forecasted that reduction in workforce and population aging are in progress simultaneously from now on. The workforce between 15-59 years old has decreased continuously for three years from 2012 according to Chinese population statistics. Meanwhile the issue of population aging has occurred. The number of workers decreases while the personnel expanse increases. The income of the person who lives in urban and city increases, but the laborer who doesn't also mind the low personnel expenses decrease. Working away from countryside workers retain decreasing, so it will become difficult to secure cheap workforce like before.

Therefore the conventional economic growth model is coming to a deadlock. So far, the pattern of importing intermediate \& capital goods, processing with enough low expense workforces and exporting overseas was adopted. But the current situation in China has changed distinctly. The production cost is uprising along with the increase of personnel expense, and the competitiveness of export declines more with high RMB. As a result, it is essential to shift the model of Chinese economic growth from "export overseas" by "low labor cost" to "domestic consumption" by "productivity improvement" from now on.

\section{Environmental Pollution and the Limit of the "Energy Waste" Production System}

The waste of energy consumption is also severe with expansion of the production scale as another feature of the Chinese economic growth. High growth is accompanied with the consumption of natural materials, but quantitative growth is reaching the limit. For example, at the beginning of 21 century, China has consumed $46 \%$ of world-stock iron \& steel, $45 \%$ of coal, $48 \%$ of concrete, $10 \%$ of petroleum \& gas, with only $8 \%$ of world GDP. In 2011, China consumes 21\% of world energy, accounting for $25 \%$ of world CO2 emission, which is the top in the world. China occupies only $10.5 \%$ of world GDP, less than $50 \%$ of American GDP.

Industrialization is achieved in China in two digits growth-speed for long period, on the other hand, people's indignation is raising by pollution of air, soil and water. For example, most of northern areas are covered by smog clouds with the aggravated air pollution level of China in recent years. Beijing is the worst area with its PM2.5 density reaching 505 micrograms in one cubic meter, which is 20 times of the safe limit value WHO admits. It is not only risky for human being. Plants are also affected without enough photosynthesize, and food supply is more concerned.

Therefore the conventional way to emphasize only to increase production won't be in common use any more from now on. The Chinese government is also going to convert its model with pursuit only for economic growth at the expense of environment. The limitless expansionary policy leads to serious environmental pollution for 30 years, so the government authority has to carry out sure punishment and reward environment policy. The policy is restraining related companies spreading serious environment pollution and local authority focusing only on economic growth. 
Divisions of "energy waste" such as electricity generation, coal, iron \& steel, concrete and glass, Implementation of measures has been considered already such as blockade of old factory and termination of outdated equipment. Moreover, industrial sophistication, production method conversion and technological innovation are under consideration with the adaptation of new energy-saving technique and equipment.

\section{Change of the Chinese Market and Opportunity of Japanese Company}

\section{From Made in China to Made for China}

The international competitiveness of the products made in China exported to foreign countries is weaker by the up of personnel expenses and RMB exchange rate. In particular, concerning the production of the labor concentration, both foreign invested and Chinese manufacturers shift to South East Asia and Africa where their labor cost is lower. For example, some multinational companies like UNIQLO, Nike, Foxconn and Samsung have withdrawn from China and begun to establish their factories in South East Asia and India. Unlimited to labor concentrated products section, some of Japanese makers whose made in China production for their domestic market cannot make any profit in case of including transportation coast and have to flow back their production to their home country due to the increase of production cost in China. For example, Japanese companies like Panasonic, Daikin, Sharp and TDK have transferred their production back to Japan from China.

Present Chinese economic growth has slowdown actually compared with rapid growth in the previous 30 years, but it still continues growing about $6 \% \sim 7 \%$. The Chinese economic high growth is not doubtful comparable with the growth in Europe, America and Japan, which also compares favorably with other emerging countries. In 2015, the GDP per person in China has reached \$8, 000. In case of the increase of 6\% every year, the GDP per person in China will be expected to exceed 10 thousand dollars in five years. China is still attractive to Japanese company with its second-largest economy power and its large scale. The number of the Japanese-ventured companies which withdrew from China in 2014 remains same as last year mostly, while capital reduction companies decreased 3.2\%. Japanese newly invested companies in China have increased 3.5\% in January 2015, and the introduction of foreign capital amount is increasing $3.2 \%$ by an execution base.

After all, the Chinese competitiveness as a production base of exportation is weakened, but as developing huge market, China has become more attractive. The Japanese makers with distinct achievement in the Chinese market, like Nissan, Daikin and Toto are undertaking marketing thoroughly. They are concentrating on product performance improvement and redesign according to the current state of China and the establishment of showroom from metropolis to cities.

The products exclusively for the Chinese upper class are not merely produced in China, actually some products are produced overseas and exported to China. The volume of sales in the Chinese market of brand, luxury cosmetics and car keep increasing every year, and China becomes the biggest market of these manufacturers. Referring to BMW world sales volume in 2012, China accounts for $28 \%$ with the top position, much more than German and America with 16\%, UK with 7\%, Italy and France with 3\%. The Japanese China-bound export amount was 13 trillion and 384.4 billion JP yen of 6\% more in 2014 year-to-year, breaking the record for the past two years consecutively. Concerning the classification of export items, there are $72.8 \%$ increase of communication device, $20.8 \%$ increase of automobile and $4.6 \%$ increase of scientific optical instrument which is favorable respectively. 


\section{Market of Industrial Goods and Needs of Productivity Improvement}

The productivity up and industrial superiority are urgent tasks for China, deprived of its competition predominance as cheap workforce. According to International Federation of Robotics (IFR), China purchased one-fifth of world industrial robotics in 2012 (60\% increase of purchase volume of last year), which has become the biggest buyer of industrial robot for the first time beyond Japan ${ }^{4}$. Nonetheless, Korea held 396 units, Japan held 332 units in 2012, referring the endowment per 10 thousand people, while China held only 23 units, so the growth potentiality in the Chinese robot market is still enormous ${ }^{5}$. The foreign manufacturers of industrial robot are also accelerating their development in the Chinese market against the background of active demand. Six Japanese makers comprise half of sales share in the Chinese robot market, with its superiority standing out.

Japanese manufacturing industry is also converted into “export to Asia of industrial goods” from "export to Europe and America of finished goods" (see Figure 4). China has become the biggest market of industrial goods now. Japanese makers like Panasonic, Hitachi, Toshiba, Sharp, Daikin, Mitsubishi Electric, Mitsubishi Motors and Toyota have supplied their key parts and components to Chinese makers for decades. Kawasaki Heavy Industries and KYB account for 50\% of their sales volume of the hydraulic pressure equipment for construction equipment in China. It is the mainstream that Japanese industrial goods are exported to China, the mechanical equipment is utilized in China and the finished products are sold in the Chinese market (Shintaku, 2010).

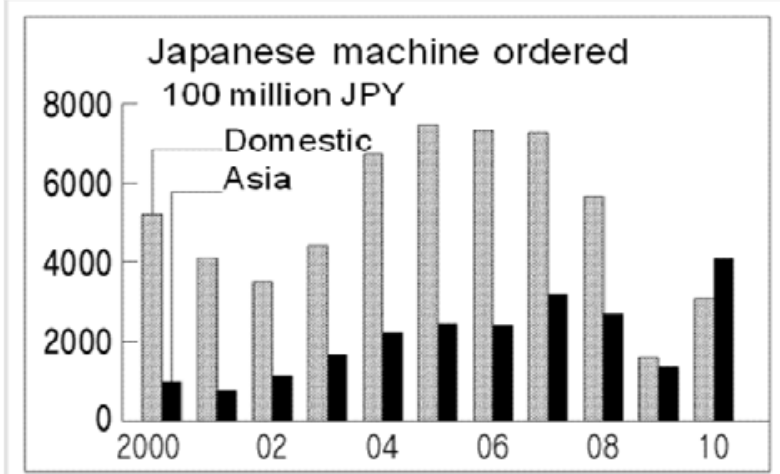

Figure 4. Coal comparison of consumption efficiency between Japan and China (electric utility and iron manufacturing, 2010).

Source: Nikkei (Japan Economic Times), September 10, 2011, p. 12.

Along with the increase of Chinese labor cost and strong RMB, Japanese labor cost against Chinese labor cost is about five times at present, of 30-50 times 30 years ago. The Japanese companies have achieved excellent results so far by their sustained efforts on productivity up. Therefore Japanese manufacturers are confident in the further expansion of Chinese domestic demand, compared with Korea and Taiwanese enterprises which pursue only inexpensive workforce and keep moving over their factories. Japanese makers have invested in their factory automation instead of decreasing workforce and making effort on cost reduction by increasing local production efficiency with the adoption of their unique management system and production equipment.

\footnotetext{
4 Economics Express, edited by Zhonghui Technology Consulting Company, Ltd., volume 4774, June 3, 2014.

${ }^{5}$ Financial Times, USA Tuesday June 10, 2014, p. 15.
} 
According to the article of Nikkei (Japan Economic Times), August 18, 2011, Nissan with its one-fourth production in China, increases its special robot in welding line in its primary factory in Guangzhou. The automation rate which indicates the ratio of the mechanized number of process is predicated up to $50 \%$ from current 30\%. From 2012 No. 2 factory has introduced latest painting equipment and promoted its labor-saving. TDK with 18 electronic component factories in China has introduced an exclusive machine in the process of coil winding which realize $70 \%$ of automation rate in its factory in Amoy (Xiamen). Production efficiency of whole factory is promoted to two times till March 2012 than one before the 2008 world financial crisis. YKK, giant fastener maker, with its 25\% production in China, has established its R\&D center in Shanghai, pulled up its production efficiency by improving employee's skill as well as the introduction of automatic transportation line in its factory.

So far it is simply distinguished by design and complicated process carried in Japan, production especially simple assembly conducted in China (Fujimoto, Amano, \& Shintaku, 2009, pp. 3-27). There are stereotype such as high separation rate and difficulty of securing multi-skilled workers in teamwork. But long-term stabilization of employment by Chinese urbanization (from work away home workers) is prospective, and the condition of multi-skilled worker education and the relocation of technological concentration division are arranged. There are also some regions with relatively high industrial average stability rate in China. The region is equipped with suitable working environment as low separation rate, enough supply of design engineer and integral product (with adjustment and optimal design from the part stage). Japanese company can organized an international labor division structure different from former Japan-China production division in such environmental change (Fujimoto, Chen, Ge, \& Fukusawa, 2010).

\section{Introduction of Japanese Energy-Saving Technology to China}

An energy demand increases rapidly with recent years' rapid economic growth in China, and has become the highest after 2009 in the world. The growth rate of the coal demand is also conspicuous along with the economic growth owing to the rapid increase of coal fired power generation and the industry with the high coal dependence. Therefore the greenhouse gas emission amount is increasing rapidly as well in recent years, and China has become world largest producer of greenhouse gas emission. On the other hand, the improvement pace of energy efficiency which increased rapidly till 2000, has slow down after 2002 with conspicuous economic growth. The energy consumption per unit GDP still up to five times than Japan and China is encountered with circumstance of unfavorable energy efficiency (see Table 3).

Table 3

World's Primary Energy Consumption per Unit GDP (TPES/GDP (Toe Per Thousand 2005 USD)

\begin{tabular}{lllllll}
\hline Country & Year & 1980 & 1990 & 2000 & 2010 & 2011 \\
\hline China & 2.25 & 1.40 & 0.75 & 0.62 & 0.62 & n/a \\
Japan & 0.14 & 0.11 & 0.12 & 0.11 & 0.10 & 0.10 \\
Korea & 0.29 & 0.26 & 0.28 & 0.25 & 0.25 & 0.17 \\
United States & 0.31 & 0.24 & 0.28 & 0.17 & 0.16 \\
Germany & 0.20 & 0.16 & 0.13 & 0.11 & 0.10 \\
\hline
\end{tabular}

Note. TPES = Total Primary Energy Supply.

Source: OECD Energy Balance.

There are many technology and plants with much lower efficiency compared in China with Japan. Referring to the coal utilization efficiency respectively of iron manufacturing industry and electric utility 
industry, it is just $90 \%$ of Japan in coal-fired electric utility and $60 \%$ of Japan in iron manufacturing industry (see Figure 5). For example, if the coal utilization efficiency of all iron manufacturing plants and electric utilities in China can be pulled up to Japanese standard, coal consumption amount can be reduced 21.3\% without the execution of special additional measures. Japanese technology is very valuable to restrain Chinese energy demand (Fujinami, 2013).

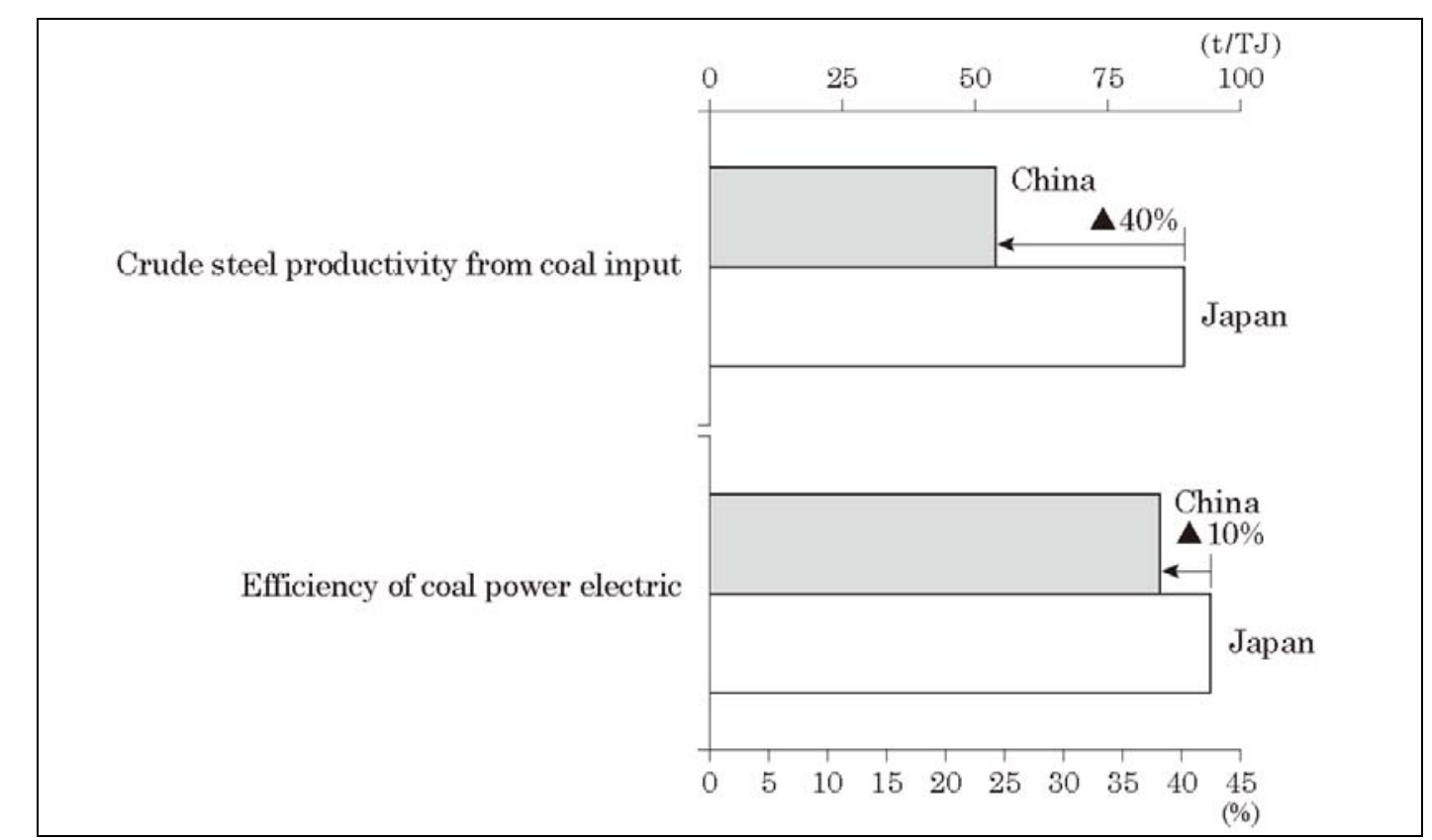

Figure 5. Coal comparison of consumption efficiency between Japan and China (Electric utility and iron manufacturing, 2010).

Source: Based on the database of IEA, drafted by Japan Research Institute.

Note. Based on the equation of $\mathrm{TJ}=10^{12} \mathrm{~J}$, petroleum conversion equals around 24 ton..

In case of no changes in Chinese energy demand structure, an energy demand as well as economic growth will keep increasing from now on. China is supposed to be the biggest importing country of natural gas and petroleum for medium-to long term, which is predicted to be extremely important risk to Japanese energy. In order to reduce risk of energy security, the energy consumption restraint support for China becomes important for Japan. It's acknowledged as national interests for Japan to restrain the Chinese energy consumption by introducing Japanese excellent energy-saving technique to China (Fujinami, 2013).

Therefore it's expected to introduce Japanese energy-saving technology and its experience up until now to China. So the selection of introduced technology is important. The technology diffusion without future sale expansion in all over Japan is maybe better to be introduced to China. Air pollution with PM2.5 mainly due to the excessive coal consumption has intensified in urban cities like Beijing at present. Japanese companies are expected to have big business opportunity for the increasing demand of air cleaner filter, volatile organic compound (VOC) measures, gas desulfurization and dust collector.

\section{New Way of Mutual Benefit of Japanese and Chinese Companies}

Japanese companies own more advanced R\&D ability and know-how of energy saving production than Chinese makers. The advantage of Japanese companies lead to the profit maximization referring to the supply of machine, component, semi-processed product and material to China. For example, the car made by Chinese 
manufacturer equipped with an engine made by Toyota and Mitsubishi Motors at the doubled price is even more popular than same-model car equipped with an engine made by Chinese makers. Daikin, Toshiba and Hitachi have made a distinct profit by selling their core items, such as inverter compressor to Chinese air conditioner makers.

According to the survey of the Organization for Economic Co-operation and Development (OECD), Apple has created near half of the value of smart phone, "iPhone4", while Japanese company $1 \%$ value even though it has supplied more than $60 \%$ of core component ${ }^{6}$. It is a challenge for Japanese company not to be limited by its technological espousal and try to create additional value by cooperation with Asia, as its main profit source (see Figure 3). It is essential to align the profit making technology with the growth of company at the same time.

Chinese companies will introduce energy-saving technology and equipment, as well as the know-how of energy-saving and productivity improvement aggressively under the pressure of environmental pollution and the increase of the production cost in the near future. In other words, Japanese companies have become supported by local Chinese manufactures which play active role at expanding Chinese market. As a result, the relation between Japanese company and Chinese company is changing rather reciprocally. More Japanese engineer will be assigned to Chinese local company guidance and more small and medium companies will advance to China vigorously from now on, so the existence of Japan as parent factory (employment maintenance, technological advancement and domestic new industry support) will probably become more and more important.

The technology selection becomes indispensable upon with the technology introduction to China. Chinese business environment is not under proper circumstance for the latest patent and core technology. It is expected to make some efforts on the risk reduction of Japanese company by assigning official facilities with specialist of judicial \& taxation affairs to China, and promoting the recognition to Chinese business manner and intellectual properties to the highly reliable situation by government-level negotiations.

\section{Conclusions}

The production cost is uprising along with the increase of personnel expense, and the competitiveness of export decreases more with high RMB in recent China. In particular, the production of the labor concentration type product like apparel and miscellaneous goods are transferred to as South East Asia and Africa with lower labor cost. Unlimited to labor concentrated products section, some of Japanese makers whose made in China production for their domestic market cannot make any profit in case of including transportation coast and have to flow back their production to their home country due to the increase of production cost in China.

Competitive as production base for export is subverting, but China as a huge developing market, is still very attractive. China as world factory has become world market. The consumption market of middle class is growing rapidly following upper class. The products for the Chinese customer are not merely produced in China, actually some products are produced overseas and exported to China. Japanese company should appeal its value based on the high quality (sophisticated function) more for Chinese customer.

The productivity up and industrial sophistication are urgent tasks for China, deprived of its competition predominance as cheap workforce. Industrialization is achieved in China, on the other hand, people's indignation is enhancing by pollution of air, soil and water. Under the pressure of environment pollution and

${ }^{6}$ Nikkei (Japan Economic Times), May 14, 2013. 
increasing costs, Chinese companies have strong desire for the introduction of both energy saving technology and equipment and their know-hows of energy-saving and productivity increasing from the Japanese companies. The introduction of Japanese excellent energy-saving technique \& equipment, know-how of productivity increasing to China will be big business opportunity for Japanese company.

On the other hand, new competition in the Chinese market has become more intensive. The Korean enterprise having a hard time at a market of Europe and America by its own strong currency is currently accelerating local production in China. Hyundai Motors established both its new car factory in Chungking in 2016, and factory for commercial cars, like truck. Hyundai has announced its productive capacity of 1.51 million, more than $40 \%$ of 2013 in China. Additionally there are many cases which show the degree of attention of the Chinese market. The Chancellor of Germany, Merkel carried out many business negotiations regarding new energy, energy saving technology, environment protection and urbanization, in July 2014, accompanying by more than 90 entrepreneurs during her 7th visit to China. Sheldon Lavin, Chairman and CEO of American OSI group visited China in July 2014, apologized directly with an exception by the judgement to suppress damage in a minimum for its business continuation because of the problem that a subsidiary company in Shanghai selling its processed product with expired meat. Further attention will be necessary to future's Chinese market.

\section{References}

Amano, T. (2009). Analyzing view of emerging market strategy: The research of interdisciplinary approach based on management resource. Journal of JBIC International Research Office, 3, 69-78.

Shintaku, J. (2010). The competiveness of industry material is the key. Nikkei (Japan Economic Times), October 1, 2010, Economy Classroom.

Chen, J. (2014). Asian business strategy and market research. Finnish: Minerva Publishing.

Chen, J., \& Mori, M. (2014). Business strategy of the Chinese market. Shinzansha Publisher.

Fujimoto, T., Amano, T., \& Shintaku, J. (2009). International management strategy of manufacturing-Asia industry geography. Yuhikaku Publisher.

Fujimoto, T., Chen, J., Ge, D. S., Fukuzawa, M. (2010). Maldistribution of organization ability and location choice of a Japanese-ventured company—case study in Dalian. International Business Study, 2(2), 35-46.

Fujinami, T. (2013). The structure change of Chinese energy demand and Japanese energy strategy. JRI Review, 9, 10. 